\title{
DESIGN OF RUSSIAN LANGUAGE EDUCATION MATERIALS FOR SPORTS PROFESSIONALS
}

\author{
Leyla Dimitrova \\ National Sports Academy „Vassil Levski”, Sofia, Bulgaria
}

\begin{abstract}
Introduction: The article describes the design of a Russian textbook for special purposes, which includes authentic materials and communicative exercises. The textbook provides some principles and innovative approaches to the selection of the content of the educational material. It also provides some sample exercises for teaching sports students how to use Russian in their professional field.

Methodology. The conducted study was based on the analysis of the textbooks used to teach sport students. During the research theoretical analysis, study of materials on the subject and comparison methods were used.

Discussion. The author explains the approach to the design of educational materials, taking into account the specific nature of the universities where foreign languages is a minor discipline. It concerns the learning objectives, the curricula, the scope of language applications, etc. The article is based on the author's own experience in teaching Russian language at sports university.

Conclusions. The article establishes some main principles of designing a contemporary Russian textbook for sport specialists. Specifically, the textbook material should be systematic, functional, understandable, problematic, informative, communicative, contextual, and authentic. The practical orientation of training and the functional approach to selecting and applying linguistic material require cooperation between a Russian teacher and sports specialist in order to avoid subjective adaptation.
\end{abstract}

Key words: Russian textbook, communicative approach, foreign language communicative competence.

\section{INTRODUCTION}

One of the pressing topics in modern education in Bulgaria is its quality and the resulting competitiveness of the graduates (Doncheva, 2014). This competitiveness depends also on their ability to communicate in a foreign language. Such is the requirement to every specialist, and it is second to professional competencies in all non-language universities, getting ahead of computer literacy.

The problem about the dependence of foreign language learning methods on the peculiarities of the sports major is still an issue because it is among the insufficiently developed ones in the Bulgarian educational materials. Few works view the matters related to Russian language learning methods (Shamonina, 2013; Ganeva, Cherneva, 2012; Kapinova, 2012; Lesnevska, 2006), the older ones (Kondova, 1978; Hubavii, 1989) have already lost their significance.

In this relation, the increasing requirements to the language competence of the students at NSA "V. Levski" determine the necessity of a design of a modern system for professionally oriented Russian language studies. The ultimate goal of these studies is development of communicative competence in the professional field of sport. This work briefly defines the need of communication purposefulness of language learning for specialized sports specialists. The manuscript also determines the necessity of creating a new curriculum and language education materials oriented towards the special needs of sports students and meeting the contemporary goals of the specialized Russian language acquisition in this field.

The aim of this study is a theoretical rationalization of contemporary peculiarities in Russian language teaching in sports universities and determining some applied-practical possibilities for optimization of this process.

Object of the research is the process of language communicative competence acquisition among students at NSA "V. Levski” who study Russian.

Subject of the research is the organization, contents, and specialized methods for Russian language 
learning for communicative purposes in the field of sport.

METHODOLOGY. The conducted study was based on the analysis of the textbooks used to teach sport students. During the research theoretical analysis, study of materials on the subject and comparison methods were used.

"Communicative competence in language learning is a combination of knowledge about: the system of language and its units, the way they are built and their functioning in speech; the ways of formulating thoughts in the studied language and understanding others' thoughts; the specifics of different types of discussions. This is the ability of language learners to communicate in different kinds of speech activities through the means of the language and in correspondence to the topical communication tasks, to understand, interpret, and create meaningful statements" (Dimitrova, 2019). Communicative competence of those studying in the professional field of sport means their ability to organize their speech grammatically, to build it logically and consistently mostly in oral and less in written form with the aim of optimizing different aspects of their professional activities. Such a professional communication may be performed in the form of a report, presentation, interview, discussion, negotiations, business meetings, etc.

The specifics of the studies at NSA "V. Levski" is related to the academic profile of the institution which is the only specialized university in Bulgaria offering higher education in three main directions - sport, physical education, and kinesitherapy. On the other hand, the limited number of Russian language classes in the curriculum of NSA imposes a maximum purposefulness of the studies material to the professional realization of the graduates.

The interrelation between foreign language teaching methods and the particular sports major is surveyed by a limited number of authors. In publications related to the issues of teaching a foreign language in sports universities (Doncheva, 2016; Platonova, 2017; Udalova, 2017; Dimitrova, 2018) the authors mentioned the insufficient content and procedure development of the used technologies which is confirmed by the poor knowledge of professional vocabulary and the difficulties in translating authentic texts with professional content among most of the students. That is why, we need a theoretical rationalization of the peculiari- ties and difficulties in foreign language teaching at universities and we also have to create and substantiate some applied-practical possibilities for solving these problems.

We believe that one of the possible solutions of this problem might be the creation and publication of modern textbooks and teaching materials containing the peculiarities of the certain major, main goals of professionally directed Russian language studies with forms and kinds aimed at developing language and speech competencies.

\section{RESULTS}

After the analysis of the accessible literature and on the basis of our own pedagogical experience, we determined as the most important the following criteria when creating a professionally directed language education materials: 1 . the selection of materials; 2 . such a proportion of grammatical and vocabulary materials which completely utilizes the limited number of foreign language classes in the curriculum of NSA; 3. connection between the contents of language studies with the other subjects, i.e. use of interdisciplinary relations.

The selection of the materials for the Russian language course should consider the main goals of the language studies for specialists in the field of sport. The materials have to be interesting and informative for the students, to help them in their preparation for their future professional activities, and to assist their further professional development. In the process of Russian language studies great attention is paid to working with texts as sources of the lexical and terminological units needed, and also as the newest information in the professional field. Since the aim of specialists' education is creating abilities to use the language as an instrument for real communication in polycultural society, the texts should be authentic. These are original texts created for real conditions of socialization, not educational situations. That is why one should use pragmatic texts, magazine and newspaper articles, regulations of sports competitions, tourist and advertising brochures, and Internet sources. Through such texts, learners receive knowledge in Russian language about the contents of the professional field (professional and scientific vocabulary - words, terms, grammar) and at the same time develop their abilities to search for, process, and use professional information from foreign sources, which, in fact, is the essence of foreign language professional competence. 
In the process of the creation of educational materials in Russian language for specialized sports specialists we used several ways to achieve a balance between grammar and vocabulary: 1 . when teaching new vocabulary, the lecturer follows the principle of a single difficulty, i. e. the new words are taught on the basis of already learnt grammar material. 2. The principle of combination where the selected words and expressions to be learnt are grammatically able to be combined which makes them significant for communication in the field of sport. 3. Using the principle of word formation, the lecturer selects lexical units with a high capacity for forming new words by adding affixes.

The formation of habits for acquisition of general and specialized vocabulary is made on the basis of numerous grammatical and lexical exercises where the most typical of a certain professional field grammar structures and speech clichés are practiced.

The review of the exercises for development of a linguistic communicative competence directed us towards their dividing into groups according to two main indicators - their type and contents. This summary can be presented in the following table format:

Table 1. Exercises for development of linguistic communicative competence

\begin{tabular}{|c|c|}
\hline Type of exercise & Exemplary contents \\
\hline \multicolumn{2}{|l|}{ LANGUAGE EXERCISES } \\
\hline $\begin{array}{l}\text { 1. Exercises for identification and differenti- } \\
\text { ation }\end{array}$ & $\begin{array}{l}\text { Match the sentences from the left and right column to make } \\
\text { meaningful statements. Widen the sentences following the } \\
\text { example and using the new words and expressions. }\end{array}$ \\
\hline 2. Exercises for substitution & Make sentences using the words given. \\
\hline 3. exercises for transformation & $\begin{array}{l}\text { Widen the sentences following the example and using the new } \\
\text { words and expressions. }\end{array}$ \\
\hline 4. Constructive exercises & $\begin{array}{l}\text { Construct five sentences by using } \\
\text { the models and expressions given. }\end{array}$ \\
\hline 5. Translation exercises & Translate the sentences into Russian. \\
\hline \multicolumn{2}{|l|}{ CONDITIONAL-SPEECH EXERCISES } \\
\hline 1. Imitation exercises & $\begin{array}{l}\text { Agree (or disagree) with the given exercises and substantiate } \\
\text { your opinion using the model. }\end{array}$ \\
\hline 2. Transforming exercises & Refute the following statements using the example. \\
\hline \multicolumn{2}{|l|}{ SPEECH EXERCISES } \\
\hline $\begin{array}{l}\text { 1. Exercises for asking and answering } \\
\text { questions }\end{array}$ & $\begin{array}{l}\text { Make three questions based on the text } \\
\text { you have read and prepare answers. }\end{array}$ \\
\hline 2. Situation exercises & $\begin{array}{l}\text { Make a dialogue on the basis of the suggested plot using the } \\
\text { words and expressions given. }\end{array}$ \\
\hline 3. Reproductive exercises & $\begin{array}{l}\text { Read the text and prepare a detailed story retold } \\
\text { on the basis of key expressions and word combinations. }\end{array}$ \\
\hline 4. Descriptive exercises & $\begin{array}{l}\text { Tell us about the sport you practice. Characterize it by using the } \\
\text { following vocabulary models. }\end{array}$ \\
\hline 5. Discussion exercises & Read the text, discuss it, and answer the questions. \\
\hline 6. Composition exercises & $\begin{array}{l}\text { Prepare a monologue on the basis of the plan } \\
\text { and the list of obligatory expressions. }\end{array}$ \\
\hline
\end{tabular}

Forming habits in different kinds of speech acti- following topic blocks: "At the hotel", "At the restauvities seems purposeful because of the close relation rant", "Sport and recreation", "At the SPA center", between the foreign language and the subjects stud- "Beach tourism", "On the ski track", "In the mounied in a major. This relation provides a successful tain", "Holidays and entertainment". When selectacquisition of the professional foreign language ing the topic contents, we used various sources of vocabulary, develops the abilities for communica- information: professionally oriented authentic mation on topics related to a major. On the basis of terials; texts taken from contemporary newspapers, the research of the curricula, of the interdisciplin- magazines, the Internet sites; authentic teaching ary relations, and the possibilities for professional materials published by Russian universities; video realization of the students at NSA, the teaching ma- and audio materials on the different topics. Each terials in Russian language were grouped into the topic introduces characteristic key words, expres- 
sions, and basic grammar rules. A connection with the previous topics is made, the place of the topic is situated in the general program and the internal connections of the theoretical material and practice are determined. Each class has a definite block, basic terms, grammar frame, and speech patterns needed for the language communication on the topic/situation.

The literary review, the summary of the gained methodological experience, and our practical observations helped us to establish our author position about the creation of teaching materials. Our thesis found practical realization in the created "Russian language education materials for students at NSA "V. Levski". The two parts of the practical education materials were created using the abovementioned criteria for communicative purposefulness of education and professional application of the material learnt.

The format of education materials supposes a smaller volume compared to a textbook. It requires a precise balance between the theoretical and practical parts, between grammar and vocabulary. At the same time, the almost unlimited free access to electronic and online based resources enables finding authentic professionally oriented texts. This peculiarity of modern education enabled us not to include the selected authentic texts in the hard copy but to record them in a separate CD.

\section{CONCLUSIONS}

1.The analysis of the methodological literature and our own teaching experience show that we need to further consider the principles of professionally oriented foreign language learning and we need to look for conformity between the contents, on the one hand, and the methods and means used in the educational process, on the other hand.

2.Sports texts which add to each other's contents create the basis on which sports students should develop their habits and skills in the different kinds of speech activities. The usage of sports topics provoking personal interest in sports students is an important means for stimulation of their oral activity.

3. When creating efficient education materials, we should consider the following factors: the future specialty of the students; their professional motivation; their level of foreign language acquisition; the specifics of development of fo- reign language competence in a particular professional field.

4. The creation of profiled education materials aimed at development of Russian communicative competence of sports students helps achieving specific goals in the course of the education process. The structure and contents of our "Russian language education materials for students at NSA "V. Levski", as well as the system of professionally oriented exercises allows its use both under the guidance of a lecturer and as self-teaching materials. The work with the education materials will help in: perceiving the different kinds of speech activities (speaking, audio, reading) in Russian language on the basis of lexical-grammatical minimum with sports orientation; learning a certain amount of general vocabulary which is widely used in the field of sport; learning basic terminology in students' major; developing skills for conscientious use of the learnt vocabulary material in oral speech; acquiring habits for making dialogues and monologues by using the most common and relatively simple lexicalgrammatical means in the field of a certain professional communication; creating abilities for seeking information in Russian language about students' major.

\section{REFERENCES}

Galskova, N., N. Gez (2006). Teorija obuchenija inostrannym jazykam. Moskva, Akademia.// Гальскова, Н., Н. Гез (2006). Теория обучения иностранным языкам, Академия, Москва.

Ganeva, K., N. Cherneva (2012). Njakoi idei za izpolzvane na suvremenni pedagogicheski podhodi I tehnologii v uchebnik po ruski ezik za nachinaeshti. Gabrovo, Eks-pres. // Ганева, К., Н. Чернева (2012). Някои идеи за използване на съвременни педагогически подходи и технологии в учебник по руски език за начинаещи//Чуждоезиково обучение в системата на висшето професионално образование (сборник с научни материали). Габрово, Издателство Екс-прес. Dimitrova, L. (2017). Uchebno pomagalo po ruski ezik za studenti ot NSA „V. Levski“ - Purva chast. Sofia, NSA PRES.// Димитрова, Л. (2017). Учебно помагало по руски език за студенти от НСА „В. Левски“ - Първа част, София, НСА ПРЕС.

Dimitrova, L. (2018). Uchebno pomagalo po ruski ezik za studenti ot NSA „V. Levski“ - Vtora chast. Sofia, NSA PRES.// Димитрова, Л. (2018). Учебно помагало по руски език за студенти от НСА „В. Левски“ - Втора 
част, София, НСА ПРЕС.

Dimitrova, L. (2018). Pedagogicheski osobenosti v obuchenieto po profesionalno orientiran chuzd ezik. XXIII International conference „Lichnost, motivacija sport“. T.23. Sofia, NSA PRES. pp.203-212. // Димитрова, Л. (2018). Педагогически особености в обучението по професионално ориентиран чужд език В сб. XXIII Международна научна конферениия „Личност, мотивация, спорт", Т.23. НСА ПРЕС.

Dimitrova, L. (2019). Roljata na chuzdoezikovoto obuchenie $\mathrm{v}$ industrijata na sporta I svobodnoto vreme. Monography. p. 26. Sofia. NSA PRES. //Димитрова, Л. (2019). Ролята на чуждоезиковото обучение в индустрията на туризма и свободното време. Монография. НСА ПРЕС, София, с.26.

Doncheva, L. (2014). An implementation of a hybrid form of education in foreign language acquisition, 18th Symposium for sport and physical education of the youth - Ohrid, Macedonia.

Doncheva, L (2016). Izsledvane na efektivnostta na inovativnata sistema za prepodavane na chujd ezik pri student-sportisti. Osma mejdunarodna nauchna konferentsia "Suvremenni tendentsii na fizicheskoto vuzpitanie i sporta, ISSN 1314-2275, p.230. Universitetsko izdatelstvo "Sv. Kliment Ohridski”, Sofia, 2016. // Дончева, Л. (2016). Изследване на ефективността на иновативната система за преподаване на чужд език при студенти-спортисти. Сб. „Осма международна научна конференция „Съвременни тенденции на физическото възпитание и спорта", ISSN 1314-2275, с.230. УИ "Св. Климент Охридски“.

Dörnyei Z. (2009). The Psychology of Second Language Acquisition, Oxford University Press, Oxford.

Hubavii, M. (1989). Posobie po ruskomu jazyku dlja studentov-sportsmenov. VIF „G. Dimitrov“, Sofia. // Хубавий, М. (1989). Пособие по русскому языку для студентов-спортсменов, ЕЦНПКФКС-ВИФ „Г. Димитров“"

Kapinova, E. (2012). Tehnologija obuchenija neverbalnoтu delovomu obshteniju pri izuchenii ruskogo jazyka $v$ profesoinalno orientirovannoj vyshej shkole. Sofia. UI «Sv. Kliment Ohridski».// Капинова, Е. (2012). Texнология обучения невербальному деловому общению при изучении русского языка в профессионально ориентированной высшей школе. С.: СУ „Св.Климент Охридски.

Kondova, V. (1978). Specijalna terminologija v obuchenieto po chuzd ezik na student vuv VIF. Scientific conference "Novi metodi v prepodavaneto na chuzd ezik". Varna. // Кондова, В. (1978). Специалната терминология в обучението по чужд език на студенти във ВИФ.
Научна конференция „Нови методи в преподаването на чужд език“. Варна.

Lesnevska, D. (2006). Prepodavanije biznes ruskogo jazyka v nefilologicheskih vuzah Bolgarii. Bolgarskaja rusistika №3-4. pp.113-117. // Лесневска, Д. (2006). Преподавание бизнес русского языка в нефилологических вузах Болгарии. Болгарская русистика № 3-4, c. 113-117.

Platonova, A. (2017). Rol Internet-tehnologij v distancionnom obuchenii inostrannomu jazyku v sportivnyh vuzah I razvitii kulturnyh I nauchnyh svjazej. University science conference "Informacionnoe prostranstvo sovremennogo sporta: sociokulturnye I lingvisricheskie aspekty". Moskva. pp,151-153. // Платонова, А. (2017). Роль Интернет-технологий в дистанционном обучении иностранному языку в спортивных вузах и развитии культурных и научных связей. Материалы университетской научно-практической конференции «Информационное пространство современного спорта: социокультурные и лингвистические аспекты». М.,с.151-153.

Richards J. (2006). Communicative Language Teaching Today. Cambridge University Press - New York.

Shamonina, G. (2013). Tehnologii na urokah RKI dlja studentov-nefilologov. Electronic presentation in „Sovremennye pedagogicheskie tehnologii $\mathrm{v}$ obuchenii ruskomu jazyku kak inostrannomu“. UI „Chernorizec Hrabur“. Varna. p. 852-868. // Шамонина, Г. (2013). Технологии на уроках РКИ для студентов-нефилологов. Електронна презентация. В Сб. „Современные педагогические технологии в обучении русскому языку как иностранному“. ВСУ „Черноризец Храбър“, Университетско издателство, Варна, с. 852-868.

Stern, H. (1983). Fundamental Concepts of Language Teaching. Oxford University Press. Oxford.

Udalova, M. (2017). Formirovanie kontenta dlja distancionnogo obuchenija inostrannomu jazyku v fizkulturnom vuze. Scientic conference „Informacionnoe prostranstvo sovremennogo sporta: sociokulturnye i lingvisticheskie aspekty“. Moskva. // Удалова, М. (2017). Формирование контента для дистанционного обучения иностранномуязыкув физкультурномвузе. Материалы университетской научно-практической конференции «Информационное пространство современного спорта: социокультурные и лингвистические аспекты». М.

Correspondng autor: Leyla Dimitrova National Sports Academy "Vassil Levski", 1700, Sofia, Studentski grad E-mail: leyla.dimitrova@nsa.bg 